\title{
Antifeedant Activity of Melia azedarach (L.) Extracts to Diabrotica speciosa (Genn.) (Coleoptera: Chrysomelidae) Beetles
}

\author{
Maurício Ursi Ventura* and Márcio Ito \\ Universidade Estadual de Londrina, Departamento de Agronomia, Campus Universitário, C.P. 6001, CEP 86051- \\ 970 Londrina - PR, Brazil
}

\begin{abstract}
Studies were carried out to determine the antifeedant activity of extracts of leaves, stems, flowers and fruits of Melia azedarach (L.), the dosage activity responses to the most active extract and the effects of sunlight in the activity persistence to Diabrotica speciosa (Genn.) beetles. Extracts efficiency was determined by evaluating leaf consumption. Insect feeding was deterred by stems, fruits and flowers extracts. Flowers and fruits extracts were the most efficient. Stems extract was in an intermediate position between the two most efficient and the least one (leaf extracts). The most active extract (flowers) was sprayed at concentrations of 0, 1, 2, 3, 4, 5, 6 and $7 \mathrm{~g} / 100 \mathrm{ml}$. Feeding of D. speciosa on common bean leaves extracts decreased significantly with increasing concentrations of flowers extract, responding in a concentration-dependent manner. Two days after spraying, from 4 to $7 \mathrm{~g} / 100 \mathrm{ml}$ concentrations, feeding was totally inhibited. Four days after spraying, feeding occurred in 4-g/100 ml concentration. When common bean plants exposed to sunlight were sprayed with flowers extract $(5-\mathrm{g} / 100 \mathrm{ml})$, beetles feeding increased gradually after extract spraying. Results showed that the lack of activity under sunlight conditions was a great limitation to use M. azedarach aqueous extracts.
\end{abstract}

Key words: Insecta, Leaf beetle, Phaeolus vulgaris (L.), Deterrence, Botanical insecticide

\section{INTRODUCTION}

Extracts of Meliaceae plants have been used successfully to inhibit feeding, repel and modify the growth of insects (Reed et al. 1982). The most used species for this purpose, neem tree Azedarachta indica A. Juss., is a cheap and safe tool for insect management in less developed countries (Schumutterer 1990, Rice 1993). The neem tree is a suitable plant to be cultivated in warm weather conditions even in low rainfall and short fertility conditions (Schumutterer, 1990).

The Asian Meliaceae plant Melia azedarach L. is a very common tree in parks and public squares in South Brazil. In Northern Paraná State, its adaptation is such that reaches pest status in orchards, growing quickly with strong development. Hernández (1995) studied the effects of aqueous extracts of several exotic and wild plants of the Meliaceae family, including $M$. azedarach, to the larva of Spodoptera frugiperda (J. E. Smith, 1797). Aqueous extracts of $M$. azedarach also had antifeedant activity for the whitefly Bemisia tabaci (Genn.) (Nardo et al.1997). Carvalho \& Ferreira (1990) also obtained the same effect for Diabrotica speciosa (Genn.) beetles.

The chemistry of the antifeedant compounds has been studied in Meliaceae plants mainly in $M$. azedarach and M. toosendan Sieb. et Zucc. From M. azedarach, Nakatami et al. (1985) found the steroid ester, azedarachol (root bark) and evidenced its antifeedant activity against the larvae of Ajrotis sejetum Denis. The limonoid allelochemical toonsedanin from the bark of $M$. azedarach and also $M$. toosendan has a combination of antifeedand and growth inhibitory properties to the variegated cutworm Peridroma saucia Hübner (Chen et al. 1995). The limonoid, azedarachin C (root bark) showed antifeedant

\footnotetext{
* Author for correspondence
} 
activity to larvae of Spodoptera exiguae Hübner (Boisduval) (Huang et al. 1995). Ring-C seco limonoid, salannal, and a potent antifeedant meliacarpinin E (root bark) and four seco limonoids, salannin, deacetylsalannin, nimbolinin $\mathrm{b}$ and nimbolidin $\mathrm{B}$ were identified and their antifeedant properties were examined for Spodoptera eridania (Boisduval) larvae (Huang et al. 1996).

This research deals with the antifeedant activity of extracts of leaves, stems, flowers and fruits of $M$. azedarach; the dosage activity responses to the most active extract and the effects of sunlight on activity persistence.

\section{MATERIAL AND METHODS}

Extracts preparation. Leaves, stems and flowers of $M$. azedarach were collected in the field from blooming plants and fruits at the fructification onset. All of them were washed and dried in the oven $\left(55^{\circ} \mathrm{C}\right)$ until constant weight. Materials were triturated in a blender. Samples were kept in hermetically closed vessels in darkness until utilization. Extracts were prepared according to Hernández (1995); mixing and shaking the dried material in distillated water for five minutes, kept in darkness conditions for 24 hours and filtered in sterilized cotton.

Bioassays. Experiments were set up under controlled conditions (temperature $26 \pm 2^{\circ} \mathrm{C}$; photoperiod of $12: 12$ (L:D) h) from $6^{\text {th }}$ September to $5^{\text {th }}$ November 1995 . Leaves of common bean, Phaseolus vulgaris (L.) cv. IAPAR 16 were obtained from greenhouse plants. Insects were collected in the field with sweeping net. Two leaves and three beetles were placed in acrylic boxes $(11,5 \times 3,5 \mathrm{~cm})$. Petioles were immersed in water. Extracts were sprayed on the adaxial surface of the leaves until flowing. Consumption of leaves was established using a drawing paper. Dead insects were replaced daily.

Extracts efficiency. Treatments consisted of leaves, fruits, stems and flowers extracts $(5 \mathrm{~g} / 100$ $\mathrm{ml}$ ) and control with only distillated water. Leaf consumption was determined three days later.
Dosage activity. The most active extract was sprayed in $0,1,2,3,4,5,6$ and $7 \mathrm{~g} / 100 \mathrm{ml}$ concentrations. Leaves consumption was evaluated 2 and 4 days later.

Activity persistence. Greenhouse common bean plants exposed to sunlight were sprayed with the most active compound in the dosage to reduce feeding (dosage activity study). Control plants were sprayed with distilled water. Leaves were collected daily to replace the bioassay leaves until six days after spraying. Leaf consumption was determined daily.

Experimental Design and Statistical Analysis. Bioassays for extracts efficiency, activity persistence (6 replicates) and dosage activity (4 replicates) were conducted in a completely randomized design. Analysis of variance (ANOVA) was performed on extracts efficiency and Tukey's range test (HSD) was used to compare individual means. Data were transformed using $(x+0.5)^{1 / 2}$ constant to normalize the data and reduce heterogeneity of variances. Means and standard errors of means presented are untransformed. Dosage activity and activity persistence were interpreted by regression analysis. In the dosage activity assay equations fitting, dosages were from $0 \mathrm{~g} / 100 \mathrm{ml}$ to the first one that reduced totally insect feeding $\left(\mathrm{Y}=0 \mathrm{~cm}^{2}\right)$.

\section{RESULTS AND DISCUSSION}

Extracts efficiency. Insect feeding was deterred by stems, fruits and flowers extracts (Table 1). Flowers and fruits extracts were the most efficient. Stems extract was at an intermediate position between the two most efficient and the least one (leaf extracts). Other closely related beetles, $D$. undecimpunctata howardi Barber and Acalymma vittatum (F.) were feeding deterred by the triterpenoids from neem, azadirachtin and salannin (Reed et al. 1982). Extracts of M. azedarach also inhibited feeding of A. sejetum (Nakatami et al. 1985), P. saucia (Chen et al. 1995), S. exiguae (Huang et al. 1995), S. eridania (Huang et al. 1996), S. frugiperda (Hernández 1995) and $B$. tabaci (Nardo et al.1997). 
Table 1 - Leaf area consumed (Mean number \pm SEM) by Diabrotica speciosa in common bean $P$. vulgaris three days after treatment with Melia azadarach extracts.

\begin{tabular}{ll}
\hline Extracts & Leaf area consumed $\left(\mathrm{cm}^{2}\right)^{a}$ \\
\hline Leaves & $1.2 \pm 0.2 \mathrm{ab}$ \\
Stems & $0.4 \pm 0.1 \mathrm{bc}$ \\
Fruits & $0.3 \pm 0.1 \mathrm{c}$ \\
Flowers & $0.0 \pm 0,0 \mathrm{c}$ \\
Control & $2.4 \pm 0.4 \mathrm{a}$
\end{tabular}

${ }^{a}$ Means in the same column with different letter are significantly different by Tukey's studentized range test $(\mathrm{P}<0.05), \mathrm{n}=6$.

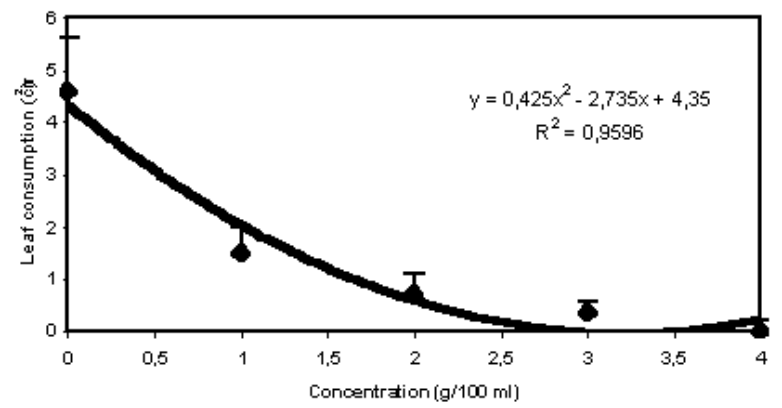

Figure 1 - Relationship between mean adult D.speciosa consumption + SEM $(\mathrm{n}=4)$ and dosage of aqueous $M$. azedarach flowers extracts two days after spraying $(\mathrm{P}<0.0001)$.

Carvalho \& Ferreira (1990) found that leaves and fruits extracts of $M$. azedarach inhibit $D$. speciosa feeding in common bean leaves. The feeding inhibition by stems, fruits and flowers extracts provides a wide range of opportunities to growers use them to manage the pest during the year. In the end of winter/beginning of spring season plants produce a great amount of flowers. Stems are available from beginning of spring to fall season. Fruits are produced in spring/summer season. Furthermore, dried structures may be kept in dark conditions to be used later. Flowers are particularly interesting to be used mainly because they are easier to be dried and triturated than fruits and stems are.

The leaf extracts lack of effect on feeding deterrence may be related to the time of collection of plant material, because meliacins content is variable according the year season (Carvalho \& Ferreira 1990).

Dosage activity. In dose-response assay, feeding of D. speciosa on common bean leaf extracts decreased significantly with increasing concentrations of flowers extracts (Figs. 1 and 2), responding in a concentration-dependent manner. Two days after spraying, from 4 to $7 \mathrm{~g} / 100 \mathrm{ml}$ dosages, feeding was totally inhibited (until 4 $\mathrm{g} / 100 \mathrm{ml}$ used to equation fitting) (Fig. 1). Four days after spraying, feeding then occurred in 4 $\mathrm{g} / 100 \mathrm{ml}$ dose (until $5 \mathrm{~g} / 100 \mathrm{ml}$ used to equation fitting) (Fig. 2).

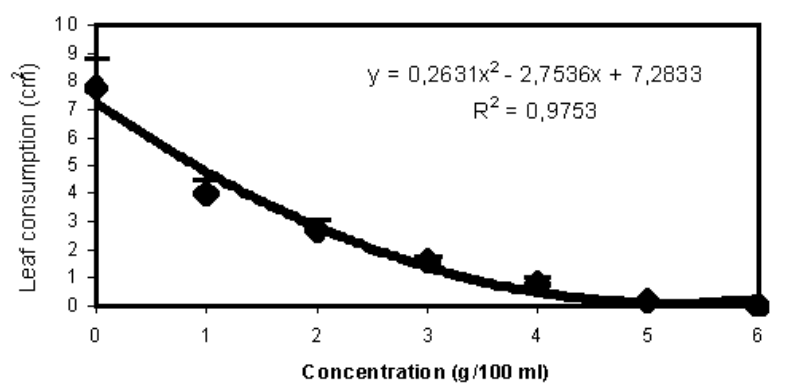

Figure 2 - Relationship between mean adult $D$. speciosa consumption + SEM $(\mathrm{n}=4)$ and dosage of aqueous $M$. zedarach flowers extracts four days after spraying $(\mathrm{P}<0.0001)$.

Activity persistence. The dosage used was 5 $\mathrm{mg} / 100 \mathrm{ml}$, considering results of the dosage activity assay (Figs. 1 and 2). Beetles feeding increased gradually day by day after flower extracts spraying (Fig. 3). In the dosage activity assay, where plants were not exposed to sunlight, leaf feeding was 0.2 and $0 \%$ in relation to the control, two and four days after plant spraying, respectively. On the activity persistence assay, leaf feeding reached 41 and 37\%, respectively. Carvalho \& Ferreira (1990) reported UV rays as a possible cause of the reduction of the antifeedants proprieties of $M$. azadirach extracts. Neem extracts also are vulnerable to UV action (Reed et al. 1982, Barnaby et al. 1989, Mohapatra et al. 1995).

Botanicals, especially those derived from Meliaceae family plants are promising tools to provide safety to a large spectrum of pests (Schumutterer 1990, Rice 1993). The demand of pesticide free yields is increasing, particularly for small area crops, like vegetables and flowers. Those are special candidates to absorb nonmammalian toxic insecticides. However, our results showed that the lack of activity under sunlight conditions was a great limitation to use $M$. azedarach aqueous extracts. Natural protections to 
UV rays such as surface waxes of cotton leaves (Pyke et al. 1993) or special formulations (Mohapatra et al. 1995) may provide longer activity. The results presented here advice for stronger efforts towards protecting compounds with antifeedant activity.

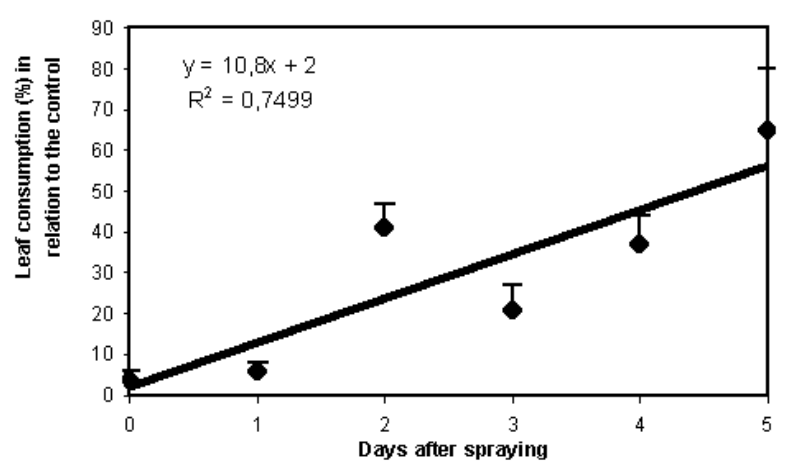

Figure - 3 Relationship between mean adult $D$. speciosa consumption + SEM $(\mathrm{n}=4)$ and dosage of aqueous $M$. azedarach flowers extracts two days after spraying $(\mathrm{P}<0.0001)$.

\section{ACKNOWLEDGEMENTS}

We thank Dr. P.M.O.J. Neves and Dr. E. Rodrigues (Department of Agronomy, Universidade Estadual de Londrina, Londrina, PR) for critically reviewing the manuscript. Édio Vizoni (Department of Applied Mathematics, Universidade Estadual de Londrina, Londrina, PR) for his assistance with equation fitting and statistics. David C. Tramontina (Laboratory of Entomology, Universidade Estadual de Londrina, Londrina, PR) for logistical help.

\section{RESUMO}

Estudou-se a atividade de inibição da alimentação de extratos de folhas, ramos, flores e frutos de Melia azedarach (L.); a atividade de resposta para doses do extrato mais ativo e os efeitos da luz do sol na persistência da atividade para adultos de Diabrotica speciosa (Genn.). A eficiência dos extratos foi determinada avaliando-se o consumo foliar. A deterrência da alimentação foi constatada para extratos de ramos, frutos e folhas. Os extratos de flores e frutos foram os mais eficientes. Extratos de ramos tiveram atividade intermediária. $\mathrm{O}$ extrato mais ativo (flores) foi pulverizado nas concentrações de $0,1,2,3,4,5,6$ e 7 g/100 ml. A alimentação de $D$. speciosa em folhas de feijoeiro decresceu significativamente com concentrações crescentes de extratos de flores, respondendo de maneira dependente da concentração. Dois dias após a pulverização, de 4 a $7 \mathrm{~g} / 100 \mathrm{ml}$, a alimentação foi totalmente inibida. Quatro dias após a pulverização, a alimentação ocorreu na concentração de $4 \mathrm{~g} / 100 \mathrm{ml}$. Plantas de feijoeiro foram pulverizadas com extratos de flores $(5 \mathrm{~g} / 100$ ml) e expostas à luz do sol. A alimentação aumentou dia a dia após a pulverização. Resultados mostram que a perda de atividade em condições de exposição ao sol é uma grande limitação para utilização de extratos aquosos de $M$. azedarach. Trabalhos de pesquisa visando formas para proteção dos compostos e que garantam a atividade de inibição da alimentação é uma grande prioridade.

\section{REFERENCES}

Barnaby, M.A.; Yamasaki, R.B. \& Klocke, J.A. (1989), Biological activity of azadirachtin, three derivates, and ultraviolet radiation degradation products against tobacco budworm larvae. J. Econ. Entomol., 82, 5863.

Carvalho, S.M. \& Ferreira, D.T. (1990), Santa-Bárbara contra vaquinha. Ciência Hoje, 11, 65-67.

Chen, W.; Isman, M.B. \& Chiu S.-F. (1995), Antifeedant and growth inhibitory effects of the limonoid toosendanin and Melia toosendan extracts on the variegated cutworm, Peridroma saucia (Lep., Noctuidae). J. Appl. Ent., 19, 367-370.

Hernández, C.R. (1995), Efeito de extratos aquosos de Meliaceae no desenvolvimento de Spodoptera frugiperda (J.E. SMITH, 1797) (Lepidoptera: Noctuidae). Tese de doutorado, ESALQ/USP, Piracicaba, 100p.

Huang, R.C.; Okamura, H.; Imagawa, T.; Tadera, K. \& Nakatami, M. (1995), Azedarachin C, a limonoid antifeedant from Melia azedarach. Phytochemistry, 38, 593-594.

Huang, R.C.; Tadera, K.; Yagi, F.; Minami, Y.; Okamura, H.; Iwagawa T. \& Nakatami, M. (1996), Limonoids from Melia azedarach. Phytochemistry, 43, 581-3.

Mohapatra, S.; Sawarkar, S.K.; Patnaik H.P.; \& Senapati, B. (1995), Antifeedant activity of solvent extracts of neem seed kernel against Spodptera litura F. and their persistency against sunlight through encapsulation. Intern. J. Pest Managem., 41,154.156.

Nakatami, M.; Takao, H.; Miura I. \& Hase, T. (1985). Azedarachol, a steroid ester antifeedant from Melia azedarach var. Japonica. Phytochemistry, 24, 11091113.

Nardo, E.A.B.; Costa A.S. \& Lourenção, A.L. (1997), Melia azedarach extracts as na antifeedant to Bemisia 
tabaci (Homoptera: Aleyrodidae). Fla. Entomol., 80, 92-94.

Pyke, B.A.; Zhen, C.S. \& M.J. Rice. (1993), Preliminary field trials with azadirachtins (AZAS), in neem seed extract, for cotton pest management. InPest Control and Sustainable Agriculture, (ed.) S.A. Corey, D.J. Dall \& D.M. Milne. CSIRO Publications, Melbourne, pp.338-341.

Reed, D.K.; Warthen JR., J.D.; Uebel E.C. \& Reed, G.L. (1982), Effects of two triperpenoids from neem on feeding by cucumber beetles (Coleoptera: Chrysomelidae). J. Econ. Entomol., 75, 1109-1113.
Rice, M.J. (1993), Theory and practice of neem-based insect pest management. In-Pest Control and Sustainable Agriculture, (ed.) S.A. Corey, D.J. Dall \& D.M. Milne. CSIRO Publications, Melbourne, pp. 335-337.

Schumutterer, H. (1990), Properties and potential of natural pesticides from the neem tree. An. Rev. Entomol., 35, 271-297.
Received: January 22, 1999; Revised: April 23, 1999; Accepted: December 23, 1999. 